\title{
Pembinaan Pada Remaja Tentang Perilaku Berpacaran
}

\author{
Siti Rachmah ${ }^{1 *}$, Eka Diah Kartiningrum ${ }^{2}$, Dhonna Anggreni ${ }^{3}$

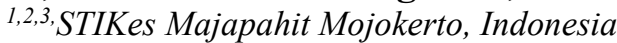 \\ rachmah64@gmail.com
}

\begin{abstract}
ABSTRAK
Remaja merupakan kelompok usia yang rentan melakukan gaya berpacaran yang menjurus pada perilaku seks bebas sehingga menyebabkan terjadinya penyebaran penyakit menular seksual maupun kehamilan diluar nikah. Tujuan kegiatan pengabdian tim STIKes Majapahit adalah agar remaja di Mojokerto mempunyai pengetahuan yang baik tentang perilaku berpacaran serta memiliki motivasi yang positif dalam menghindari perilaku seks bebas. Kegiatan pengabdian dilaksanakan pada remaja SMA di wilayah Mojokerto yang berupa upaya pembinaan tentang perilaku berpacaran dan dampaknya, perilaku seks bebas dan dampaknya, serta upaya persuatif agar remaja memiliki motivasi yang tinggi untuk menghindari seks bebas selama berpacaran. Kegiatan pembinaan dilakukan dengan menggunakan metode ceramah, diskusi dan tanya jawab. Hasil kegiatan pembinaan didapatkan bahwa terjadi peningkatan pengetahuan remaja tentang perilaku berpacaran dan dampaknya, perilaku seks bebas dan dampaknya serta terjadi peningkatan motivasi remaja dalam menghindari seks bebas. Pengetahuan merupakan domain utama dalam perilaku yang memiliki pengaruh yang kuat terhadap terbentuknya perilaku maupun motivasi tertentu. Semakin tinggi pengetahuan seseorang tentang suatu perilaku, maka semakin tinggi motivasi seorang individu untuk melakukan sesuatu. Semakin baik pengetahuan remaja tentang perilaku berpacaran dan dampaknya, maupun tentang perilaku seks bebas maka semakin tinggi motivasi yang dimiliki remaja untuk menghindari seks bebas selama berpacaran.
\end{abstract}

Kata Kunci: Pacaran, Remaja, Seks bebas, Motivasi, Pengetahuan

Received: October, 25, 2019

Revised: December 14, 2019

Accepted: February 11, 2020

\section{(c) (1) (2)}

This is an open-acces article distributed under the terms of the Creative Commons Attribution-ShareAlike 4.0 International License.

\section{PENDAHULUAN}

Gaya berpacaran remaja saat ini sudah menjurus pada perilaku seks bebas yang berdampak pada penyebaran penyakit menular seksual. Muliyati (2012) mengatakan bahwa pacaran jaman dahulu dijadikan sebagai suatu cara untuk menyeleksi pasangan dengan melibatkan pengawasan orang tua yang tujuannya adalah untuk menikah, sedangkan saat ini banyak remaja berpacaran yang tujuannya hanya sekedar untuk mengisi waktu, dan mengikuti tren, dimana hal ini orientasinya tidak untuk menikah. Menurut Lestari (2015) pacaran jaman dahulu cenderung lebih pada perjodohan yang mengarah pada pernikahan tanpa adanya perkenalan, sedangkan pacaran jaman sekarang lebih pada hubungan yang dianggap sebatas permainan. Sujarwati, Yugistyowati, dan Haryani (2014), 
menyatakan remaja saat ini lebih terbuka dan bebas untuk melakukan apapun demi menunjukkan keseriusan kepada pasangannya. Setiawan (2010), dan Hays, dkk (2011) menyebutkan bahwa perilaku pacaran remaja terbagi dalam 2 jenis, yakni perilaku pacaran sehat dan perilaku pacaran tidak sehat. Setiawan (2010) menggolongkan perilaku pacaran sehat yang terdiri dari sehat secara fisik, psikis, dan sosial, sedangkan perilaku pacaran tidak sehat terdiri dari kissing, necking, petting, intercourse.

Data di RSCM menunjukkan bahwa sekitar 15\% dari kasus IMS baru yang dilaporkan, terdiri dari anak berusia 12-22 tahun. Berdasarkan data rekam medis Poliklinik Ilmu Kesehatan Kulit dan Kelamin Divisi Infeksi Menular Seksual di RSUP dr. Hasan Sadikin tahun 2013 terdapat 900an pasien IMS, dan 9 persen dari jumlah tersebut adalah pasien berusia 10-19 tahun. Sementara RSUD Soetomo, Surabaya, mencatat ada sekitar 30 pasien IMS berusia muda setiap bulannya (data bulan April, 2018). Sedangkan kasus di Amerika sampai pertengahan April 2018 menunjukkan bahwa setengah dari 20 juta kasus IMS (Infeksi Menular Seksual) baru per tahunnya terdiri dari para remaja usia 15-24 tahun, kasus IMS pada remaja di Indonesia juga sudah mulai banyak ditemukan.

Hasil penelitian Nari, J., dkk (2018) menjelaskan bahwa ada hubungan antara perilaku seks berisiko dengan kejadian penyakit menular seksual pada remaja di klinik IMS Puskesmas Rijali dan Passo. Sedangkan pengetahuan merupakan faktor utama yang menentukan perilaku seks beresiko yang dilakukan oleh remaja. Kasus mengenai perilaku seksual pada remaja dari waktu ke waktu semakin mengkhawatirkan karena perilaku seksual remaja sekarang ini sudah melebihi batas terutama pada masa remaja akhir. Control social yang tepat perlu dilakukan untuk mencegah penyebaran penyakit menular seksual. Salah satu bentuk control social adalah melalui upaya pembinaan secara langsung pada remaja agar tidak terjerumus melakukan perilaku seks yang beresiko khususnya pada remaja awal. Hasil survey peneliti tentang pengetahuan remaja mengenai perilaku pacaran dan dampaknya pada bulan Januari tahun 2019 yang dilakukan pada beberapa SMA di wilayah Mojokerto menunjukkan bahwa sebagian besar remaja mempunyai pengetahuan yang baik tentang perilaku pacaran namun hampir $70 \%$ remaja memiliki pengetahuan yang kurang baik tentang dampak perilaku pacaran. Pengetahuan yang kurang baik tentang perilaku seks merupakan salah satu faktor yang mempengaruhi penularan penyakit menular seksual dan terjadinya kehamilan usia dini. Berdasarkan hasil survey tersebut maka tim pengabdi STIKes Majapahit menyusun kegiatan pembinaan remaja tentang perilaku seks yang dilaksanakan di beberapa SMA di wilayah Mojokerto.

\section{TUJUAN}

Tujuan pelaksanaan kegiatan pengabdian masyarakat yang dilaksanakan tim STIKes Majapahit Mojokerto adalah untuk meningkatkan pemahaman remaja usia awal tentang perilaku seks beresiko di Kota Mojokerto. Beberapa tujuan khusus yang ingin dicapai antara lain:

1. Meningkatkan pengetahuan remaja awal tentang konsep berpacaran

2. Meningkatkan pengetahuan remaja awal tentang dampak perilaku pacaran

3. Meningkatkan pengetahuan remaja awal tentang dampak seks bebas

4. Meningkatkan motivasi remaja awal untuk menghindari seks bebas

\section{BAHAN DAN METODE}

Tahap pertama merupakan perencanaan kegiatan yang akan dilakukan. Proses perencanaan meliputi identifikasi kebutuhan, identifikasi potensi dan kelemahan yang ada, menentukan jalan keluar dan kegiatan yang akan dilakukan, dan membuat 
pengorganisasian kegiatan. Perencanaan disusun oleh tim pengabdian dimana disini juga bertindak sebagai fasilitator. Tahap kedua merupakan pelaksanaan kegiatan sesuai dengan yang telah direncanakan. Sedangkan tim pengabdian bertindak sebagai fasilitator. Kegiatan pengabdian masyarakat dengan media promosi kesehatan akan dilakukan adalah sebagai berikut:

1. Perkenalan

Pelaksana memperkenalkan diri pada peserta pengabdian masyarakat. Jumlah peserta pada adalah 30 orang. Siswa dikumpulkan di kelas atau aula.

2. Pre Test

Pretest dilakukan untuk mengetahui pengetahuan peserta akan dampak perilaku pacaran sebelum dilakukan penyampaian informasi.

3. Teknik Pelaksanaan Pembinaan

a. Metode Pembinaan

Metode pembinaan yang dilakukan pada remaja dengan memberikan penyuluhan di sekolah-sekolah yang terdapat di Mojokerto. Pembinaan berupa penyuluhan dengan metode ceramah dan diskusi. Remaja diberikan materi tentang pacaraan, dampak dan kerugiannya selama beberapa jam lalu diajak untuk berdiskusi tentang dampak. Dalam pelaksanaan metode ini ada kemungkinan untuk sharring remaja pada narasumber sehingga sedikitnya mampu menyelesaikan masalah yang dihadapi oleh remaja.

b. Sasaran

Remaja SMA kelas 1, 2 dan 3 yang terdaftar di sekolah-sekolah di wilayah Mojokerto

c. Waktu dan Tempat

Waktu: 2 minggu sekali sebanyak 4 kali selama bulan November 2019 - Januari 2020

4. Post test

Posttest dilakukan untuk mengetahui pengetahuan remaja akan dampak perilaku pacaran setelah dilakukan penyampaian informasi.

5. Penutup

Pada penutup juga dilakukan sesi Tanya jawab berhadiah bagi peserta yang menjawab benar pertanyaan yang diberikan.

\section{HASIL}

Hasil kegiatan pembinaan yang dilaksanakan pada remaja sekolah dijelaskan dalam tabel 1 sebagai berikut.

Tabel 1 Pengetahuan Remaja Tentang Perilaku Berpacaran

\begin{tabular}{llccccc}
\hline \multirow{2}{*}{ Mo } & Materi & Tingkat & \multicolumn{2}{c}{ Pre Test } & \multicolumn{2}{c}{ Post Test } \\
\cline { 3 - 6 } & Pembinaan & Pengetahuan & Frekuensi & Prosentase & Frekuensi & Prosentase \\
\hline 1 & konsep & Baik & 5 & 10 & 25 & 50 \\
& berpacaran & Cukup & 25 & 50 & 25 & 50 \\
& Kurang & 20 & 40 & 0 & 0 \\
\hline 2 & dampak & Baik & 1 & 2 & 5 & 10 \\
& perilaku pacaran & Cukup & 20 & 40 & 35 & 70 \\
& Kurang & 29 & 58 & 10 & 20 \\
\hline 3 & dampak seks & Baik & 5 & 10 & 15 & 30 \\
& bebas & Cukup & 15 & 30 & 25 & 50 \\
\hline
\end{tabular}


Journal of Community Engagement in Health

http://jceh.org

ISSN: 2620-3758 (print); 2620-3766 (online)

https://doi.org/10.30994/jceh.v3i1.30

Vol.3 No.1. March 2020. Page.33-38

\begin{tabular}{|c|c|c|c|c|c|c|}
\hline & & Kurang & 30 & 60 & 10 & 20 \\
\hline \multirow[t]{3}{*}{4} & motivasi remaja & Baik & 5 & 10 & 15 & 30 \\
\hline & awal untuk & Cukup & 25 & 50 & 25 & 50 \\
\hline & $\begin{array}{l}\text { menghindari } \\
\text { seks bebas }\end{array}$ & Kurang & 20 & 40 & 10 & 20 \\
\hline
\end{tabular}

Hasil kegiatan pengabdian menunjukkan adanya peningkatan pengetahuan remaja tentang konsep berpacaran, dampak perilaku pacaran, dampak seks bebas serta terjadi peningkatan motivasi remaja dalam menghindari seks bebas. Nilai rerata paling tinggi pada tingkat pengetahuan remaja adalah pada konsep tentang perilaku berpacaran.

\section{PEMBAHASAN}

Masa remaja sebagai masa peralihan antara anak -anak menuju dewasa merupakan masa yang sangat rawan terhadap berbagai pengaruh dari luar. Stimulasi yang tepat pada masa remaja mempengaruhi status perkembangannya (Rumini \& Sundari, 2004). Faktor lingkungan khususnya pengaruh teman sebaya merupakan faktor dominan yang mempengaruhi perkembangan remaja, khususnya perkembangan seksual. Perilaku dan hubungan seksual anak remaja saat ini seperti gaya berpacarannya sangat berbeda dengan remaja dahulu. Muliyati (2012) mengatakan bahwa pacaran jaman dahulu dijadikan sebagai suatu cara untuk menyeleksi pasangan dengan melibatkan pengawasan orang tua yang tujuannya adalah untuk menikah, sedangkan saat ini banyak remaja berpacaran yang tujuannya hanya sekedar untuk mengisi waktu, dan mengikuti tren, dimana hal ini orientasinya tidak untuk menikah. Menurut Lestari (2015) pacaran jaman dahulu cenderung lebih pada perjodohan yang mengarah pada pernikahan tanpa adanya perkenalan, sedangkan pacaran jaman sekarang lebih pada hubungan yang dianggap sebatas permainan. Sujarwati, Yugistyowati, dan Haryani (2014), menyatakan remaja saat ini lebih terbuka dan bebas untuk melakukan apapun demi menunjukkan keseriusan kepada pasangannya. Akibatnya kecenderungan remaja terjerumus pada perilaku seks bebas sangat besar. Upaya stimulasi, pembinaan dan monitoring yang terstruktur antara pihak sekolah, kelompok remaja dan kelompok social masyarakat harus dapat dilaksanakan dengan baik agar penyebaran penyakit menular seksual akibat perilaku seks bebas khususnya pada usia remaja yang merupakan asset bangsa dapat dihindari.

Kegiatan pembinaan yang dilakukan oleh tim pengabdian masyarakat STIKes Majapahit menggunakan metode diskusi dengan sedikit ceramah. Remaja kurang suka digurui sehingga metode ceramah yang diberikan hanya berupa penyampaian sedikit informasi tentang perilaku seks dan perilaku pacaran namun lebih banyak menayangkan video tentang gaya pacaran remaja dan dampaknya, tentang perilaku seksual dan dampaknya baik dampak fisik maupun psikososial yang ditimbulkan. Sehingga remaja bisa membandingkan dirinya dengan role model yang ditampilkan. Pada saat diskusi, remaja lebih banyak sharring pengalaman dan informasi yang pernah didapat bahkan cenderung menyampaikan keluh kesah yang berkaitan dengan teman sebaya maupun orang tua. Metode diskusi merupakan metode pembelajaran yang lebih banyak melibatkan peserta didik dan menempatkan pemateri sebagai fasilitator. Peserta didik dibiarkan berdiskusi untuk mencari kebenaran teori yang dibahas. Metode diskusi sangat sesuai untuk pembelajaran pada anak usia remaja. Pada saat pemberian materi tentang konsep berpacaran, penulis menyampaikan tentang definisi pacaran, indicator pacaran, dan konsep pacaran yang sehat di usia remaja. Pada saat pre test hampir setengah remaja kurang tahu tentang konsep pacaran yang sehat. Anggapan tabu berpacaran dikaitkan dengan ajaran 
agama masih menjadi stigma pada sebagian besar remaja. Namun ketika dijelaskan bahwa pacaran yang sehat adalah langkah bersosialisasi dan mendukung perkembangan diri remaja maka terjadi peningkatan pengetahuan remaja menjadi cukup baik dan baik pada saat post test diberikan.

Pada pembinaan tentang dampak perilaku pacaran yang negatif maupun positif banyak terjadi pro kontra pendapat pada saat diskusi. Namun dari hasil pre dan post test didapatkan peningkatan yang cukup signifikan pada pengetahuan remaja meskipun masih ada beberapa remaja yang memiliki pengetahuan pada tingkat kurang. Pemberian materi tentang dampak seks bebas juga menimbulkan dampak yang signifikan pada remaja yang mengikuti pembinaan. Pada akhir pembinaan terjadi peningkatan motivasi remaja untuk menghindari seks bebas selama berpacaran. Upaya pembinaan yang dilakukan dengan pendekatan diskusi dan sharring mampu mempengaruhi pengetahuan dan motivasi remaja. Upaya pendidikan kesehatan yang dilaksanakan dengan menggunakan metode ceramah dan diskusi sangat efektif dalam meningkatkan pengetahuan peserta didik, dan dengan pengetahuan yang dimiliki dapat mempengaruhi sikap yang muncul terhadap fenomena yang dibahas dalam pendidikan kesehatan. Pengetahuan dan sikap saling bersinergi dalam hubungan perilaku individu akan memberikan pengaruh yang positif terhadap motivasi seseorang. Oleh sebab itu pendidikan kesehatan yang terintegrasi dan diberikan dengan metode yang sesuai dengan gaya belajar remaja masih relevan digunakan sebagai cara untuk mencegah terjadinya seks bebas dan penyebaran penyakit menular seksual. Pihak sekolah dan organisasi kepemudaan di desa seperti karang taruna hendaknya aktif melaksanakan upaya pembinaan pada remaja baik putra maupun putri sehingga memiliki pemahaman yang benar tentang perilaku seks serta mampu meningkatkan potensi diri agar menjadi generasi muda yang berguna dan inovatif.

\section{KESIMPULAN}

Kegiatan pengabdian masyarakat yang dilaksanakan selama 3 bulan pada remaja mampu meningkatkan pengetahuan remaja tentang perilaku pacaran dan dampaknya, dampak seks bebas serta merubah motivasi remaja untuk menghindari seks bebas. Kegiatan yang terintegrasi dengan baik dengan metode yang sesuai dapat memberikan kesan tersendiri bagi remaja.

\section{UCAPAN TERIMAKASIH}

Rasa terimakasih yang sebesar-besarnya diberikan kepada ketua dan LPPM STIKes Majapahit Mojokerto atas dukungan yang diberikan kepada tim pengabdian selama menjalankan program pembinaan, tak lupa dukungan dan peran serta seluruh remaja yang terlibat dalam kegiatan pembinaan, semoga kegiatan ini dapat ditindaklanjuti di tingkat desa dan dapat berperan dalam pembentukan generasi bangsa yang positif, inovatif dan tangguh.

\section{REFERENSI}

Hays, G. Danica., Michel, E.R.,Cole, F.R., Emelianchik, K., Forman, J., Lorelle, S., Sikes, A. (2011). A Phenomenological Investigation of Adolescent Dating Relationships and Dating Violence Counseling Interventions. The Professional Counselor, Vol. 1, Issue 3, 222-233.

Lestari, S. T. (2015). Perubahan Perilaku Pacaran Remaja Sekolah Menengah Pertama Negeri 2 Sendawar di Kutai Barat. eJournal Sosiatri-Sosiologi, 3 (4), 11-25. 
Muliyati. (2012). Faktor -Faktor yang Berhubungan dengan Perilaku Gaya Pacaran pada Siswa SMU X dan MAN Y Kabupaten Sidrap Propinsi Sulawesi Selatan Tahun 2012 (Skripsi yang tidak dipublikasikan). Fakultas Kesehatan Masyarakat Universitas Indonesia, Jakarta.

Nari, Jois, Zahroh Shaluhiyah, and Priyadi Nugraha Prabamurti. "Analisis Faktor-Faktor yang Berhubungan dengan Kejadian IMS pada Remaja di Klinik IMS Puskesmas Rijali dan Passo Kota Ambon." The Indonesian Journal of Health Promotion (Jurnal Promosi Kesehatan Indonesia) 10.2 (2018): 131-143.

Setiawan, I. 2010. MASTURBASI. Yogyakarta: C.V Andi offset.

Sujarwati., Yugistyowati , A., Haryani, A . (2014). Peran Orang Tua dan Sumber Informasi dalam Pendidikan Seks dengan Perilaku Seksual Remaja pada Masa Pubertas di SMAN 1 Turi. Jurnal Ners dan Kebidanan Indonesia, Vol. 2(3), 112-116

Sri Rumini dan Siti Sundari, (2004), Perkembangan Anak dan Remaja, Jakarta: PT. Asdi Mahasatya. 